\title{
Penguatan Promosi Melalui Media Website pada Hotel Alvina Pematangsiantar
}

\author{
Djoni $^{1}$, Roni Yunis*2, Suminar Ariwibowo ${ }^{3}$ \\ 1,2,3Program Studi Sistem Informasi, STMIK Mikroskil Medan \\ *e-mail: djoni@mikroskil.ac.id ${ }^{1}$ roni@mikroskil.ac.id ${ }_{2}{ }_{2}$ suminar.ariwibowo@mikroskil.ac.id ${ }^{3}$
}

\begin{abstract}
The partner in the Community Service Program (PkM) is Hotel Alvina Pematangsiantar. Seeing the need for Hotel Alvina for the use of information technology that seems not optimal, especially in supporting media ads platform. To support a better promotion, it is necessary to have a website that can increase the capacity of promotion and visitors. The implementation of the PkM program refers to a qualitative approach and is combined with the stages in the Software Development Lifecycle which have been modified into 6 stages, starting from initiation, design, data migration, development, implementation, and maintenance. The resulting website can be used by Hotel Alvina to manage hotel information, such as contact us, about us, blogs, and galleries. The website is also supported by online reservation facilities that can be used by visitors. The website that has been successfully implemented is expected to increase services and promotions for Hotel Alvina, so that it can compete and develop in a sustainability.
\end{abstract}

Keywords: website, promosi, software development lifecycle

\begin{abstract}
Abstrak
Mitra dalam Program Pengabdian kepada Masyarakat (PkM) adalah Hotel Alvina Pematangsiantar. Melihat kebutuhan Hotel Alvina terhadap pemanfaatan teknologi Informasi yang belum optimal, terutama dalam mendukung penguatan promosi. Untuk mendukung promosi yang lebih baik, maka diperlukan sebuah website yang dapat meningkatkan kapasitas promosi dan layanan kepada pengunjung. Pelaksanaan program PkM mengacu pada pendekatan kualitatif dan dikombinasikan dengan tahapan-tahapan dalam Software Development Lifecycle yang sudah dimodifikasi menjadi 6 tahapan yaitu mulai dari inisiasi, desain, migrasi data, pengembangan, implementasi, dan perawatan. Website yang dihasilkan dapat digunakan oleh Hotel Alvina untuk mengelola Informasi hotel, seperti contact us, about us, blog, dan gallery. Website juga didukung dengan fasilitas reservasi online yang dapat digunakan oleh pengunjung. Website yang sudah berhasil diimplementasikan diharapkan dapat meningkatkan layanan dan promosi bagi Hotel Alvina, sehingga dapat bersaing dan berkembang secara berkelanjutan.
\end{abstract}

Kata kunci: website, promosi, software development lifecycle

\section{PENDAHULUAN}

Perkembangan bisnis perhotelan dan adanya teknologi reservasi online melalui media internet semakin banyak diminati oleh calon tamu hotel ataupun bisnis traveling baik yang ada dalam negeri maupun di luar negeri, karena sangat mudah dan murah. Dengan internet calon pengunjung lebih mudah mencari informasi yang dibutuhkan dan dapat dengan mudah berkomunikasi dengan penyedia jasa perhotelan dimanapun dan kapanpun. Pada umumnya pada saat ini hampir semua perusahaan perhotelan sudah memiliki website yang dilengkapi dengan fasilitas reservasi online, disamping hal tersebut dengan adanya website bisa dijadikan sebagai media promosi, dan memenangkan persaingan. Website adalah sekumpulan halaman digital yang berisi Informasi yang dapat dijadikan dalam bentuk teks, suara, atau video yang dapat diakses oleh pengguna melalui halaman browser (Khadafi, Salim, \& Prabowo, 2018).

Kota Pematang Siantar merupakan salah satu kota kecil yang ada di Sumatera Utara dengan luas wilayah $79.97 \mathrm{~km}^{2}$ dan jumlah penduduk sebanyak 255.317 jiwa dan sangat menarik untuk dijadikan tempat tujuan wisata keluarga, wisata sejarah, maupun wisata religi (Pemkot, 2021). Banyak sekali tempat wisata yang di Pematangsiantar yang bisa dikunjungi, menurut portalwisata.co.id mengidentifikasi 20 objek wisata diantaranya adalah: Kebun Teh Sidamanik, Air Terjun Bah Biak, Patung Dewi Kwan Im, Manigom Nauli, Siantar Waterpark, Pemandian Bah 
Damanik, Museum Simalungun, Museum Zoologi, Taman Hewan Pematangsiantar, Pemandian Alam Sejuk, Air Terjun Mamabu, Air Terjun Katasa, Air Terjun Tonduhan, Air Terjun Sipitu Tikka, Martoba Waterpark, Tugu Becak, Pemandian Karang Anyer, Bukit Indah Simarjarunjung, Lapangan Merdeka Siantar, dan Pemandian Pulau Batu (Wisata, 2021). Melihat potensi ini mengakibatkan sangat dibutuhkannya ketersediaan sebuah layanan jasa penginapan atau perhotelan di Kota Pematangsiantar yang dapat dengan mudah di akses dan memberikan pelayanan yang baik terhadap para wisatawan yang beristirahat atau akamodasi selama kegiatan wisata.

Hotel Alvina merupakan salah satu perusahaan jasa perhotelan dan akomodasi yang ada di Pematangsiantar yang sedang berkembang dan terus berupaya untuk meningkatkan layanan serta standar kualitas hotel dari berbagai sisi. Saat ini Hotel Alvina sudah memiliki layanan kamar sebanyak 36 buah kamar dengan 5 jenis type kamar mulai dari Standar, Deluxe, Superior, Suite, dan President Suite. Disamping layanan kamar Hotel Alvina juga menyediakan Café dan Restoran, dan fasilitas-fasilitas yang lain, seperti Wifi, Room Service, dan Loundry. Upaya lain yang perlu ditingkatkan adalah pemanfaatan teknologi informasi. Hotel Alvina selain sudah menyediakan reservasi offline melalui telepon atau datang langsung pada Hotel, saat ini Hotel juga sudah memanfaatkan aplikasi seperti Traveloka, PegiPegi, Tiket.Com, NusaTrip, dan Trivago yang dapat dapat di akses oleh konsumen untuk melakukan pencarian dan reservasi secara online.

Dengan melihat belum optimalnya penggunaan TIK di Hotel Alvina, terutama terkait dengan memanajemen informasi, mengelola berita, promosi, reservasi dan agenda-agenda hotel yang dapat disimpan dengan baik. Promosi bagi sebuah hotel adalah sangat penting, karena dengan adanya promosi maka hotel akan semakin dikenal dan secara bisnis maka akan meningkatkan keuntungan. Melihat keterbatasan media promosi yang ada saat ini pada Hotel Alvina, maka diperlukan sebuah TIK yang dapat digunakan untuk mengatasi masalah-masalah tersebut, salah satu alternatif solusi TIK yang tepat adalah penggunaan website. Website dapat dijadikan sebagai media yang sangat efektif untuk menyampaikan Informasi dan promosi dengan skala akses yang sangat luas melalui teknologi internet (Andriyan, Septiawan, \& Aulya, 2020). Penguatan promosi melalui website yang dibutuhkan oleh Hotel ini dapat menggunakan teknologi Content Management System (CMS). Definisi universal dari CMS adalah sebuah sistem yang dapat menerapkan prinsip-prinsip manajemen kedalam konten, yang nantinya bisa dibuat, diedit dan dipublis (Patel, K, Rathod, R, \& Parikh, 2011). Dalam CMS dimungkinkan pengembangan Website dengan menambahkan plug-in yang dapat disesuaikan dengan kebutuhan (Hills, 2016). Dalam artikel ini, akan dibahas secara dalam tentang metode yang digunakan dalam pelaksanaan Pengabdian kepada Masyrakat (PkM) dan hasil yang sudah dicapai, sehingga dapat bermanfaat bagi mitra yaitu Hotel Alvina Pematangsiantar

\section{METODE}

Sebelum penerapan dari solusi yang ditawarkan kepada mitra, maka ada beberapa strategi dan tahapan yang harus dilakukan secara tepat dan sesuai dengan kebutuhan. Pelakasanaan PkM ini dilakukan dengan mengggunakan pendekatan kualitatif, yaitu melalui diskusi dan wawancara secara intensif dengan mitra yaitu pihak manajemen dan pengelola TIK Hotel Alvina, sehingga didapatkan beberapa kebutuhan. Pengumpulan data dan analisis kebutuhan dilakukan pada awal bulan Januari 2021 bersama mitra. Mitra menyediakan ruangan khusus yang digunakan oleh tim pelaksana, untuk mengali kebutuhan. Mitra menyediakan semua kebutuhan Informasi atau data yang diperlukan oleh tim pelaksana dan bersama-sama dengan mitra untuk mengindentifikasi kebutuhan yang diperlukan. Untuk mendukung implementasi dari analisis kebutuhan yang sudah dilakukan maka untuk tahapan selanjutnya akan mengacu pada tahapan Software Development Lifecycle (SDL) yang sudah dimodifikasi berdasarkan efesiensi dan efektifitas pengembangan website. Modifikasi SDL dapat digunakan dengan mempertimbangkan fleksibelitas dan efesiensi dalam proses-proses yang ada didalamnya serta keamanan dari website 
yang dihasilkan (Sugiantoro, Anshari, \& Sudrajat, 2020). Berikut ini pada Gambar 1, akan diuraikan tahapan-tahapan yang akan dilakukan, diantaranya adalah:

a) Inisiasi

Dalam fase ini, tim pelaksana akan menjadwalkan berbagai sesi penentuan konten website dan mendapatkan pemahaman yang mendetail tentang tujuan umum dari website, persyaratan desain, detail dari website. Tujuan dari fase ini adalah mendapat Informasi dari mitra yang nantinya dapat diuraikan pada tahapan desain yang lebih terinci dan mendukung aktifitas pengembangan. Instrumen yang digunakan beberapa pertanyaan dasar yang dapat digunakan untuk menggali kebutuhan. Kebutuhan dimodelkan kedalam Use Case Diagram. Model Use Case Diagram yang sudah disusun akan di evaluasi bersama dengan calon pengguna, dalam hal ini adalah pengelola TIK dari Hotel Alvina. Hasil evaluasi bersama akan didapatkan model kebutuhan final yang nantinya akan dilanjutkan pada fase desain.

b) Desain

Pada fase ini, persyaratan desain disesuaikan dengan kebutuhan mitra, karena mitra adalah Hotel maka, desain website mengacu pada tema yang sudah dipilih berdasarkan elemen-elemen yang dibutuhkan mitra. Pemilihan desain juga harus memperhatikan 3 buah aspek yaitu pemahaman desain, konsep desain dan pembuatan desain (Joo, 2017)

c) Migrasi Data

Fase ini, merupakan fase yang sangat penting kalau pada mitra sudah ada penyimpanan data sebelumnya, sehingga data dan Informasi apa saja yang dibutuhkan tinggal ditentukan dan dipilih untuk dimasukkan ke sistem yang akan dikembangkan. Tapi jika pada mitra belum ada data yang tersimpan sebelumnya, maka fase ini bisa dilewati dan langsung masuk pada fase pengembangan.

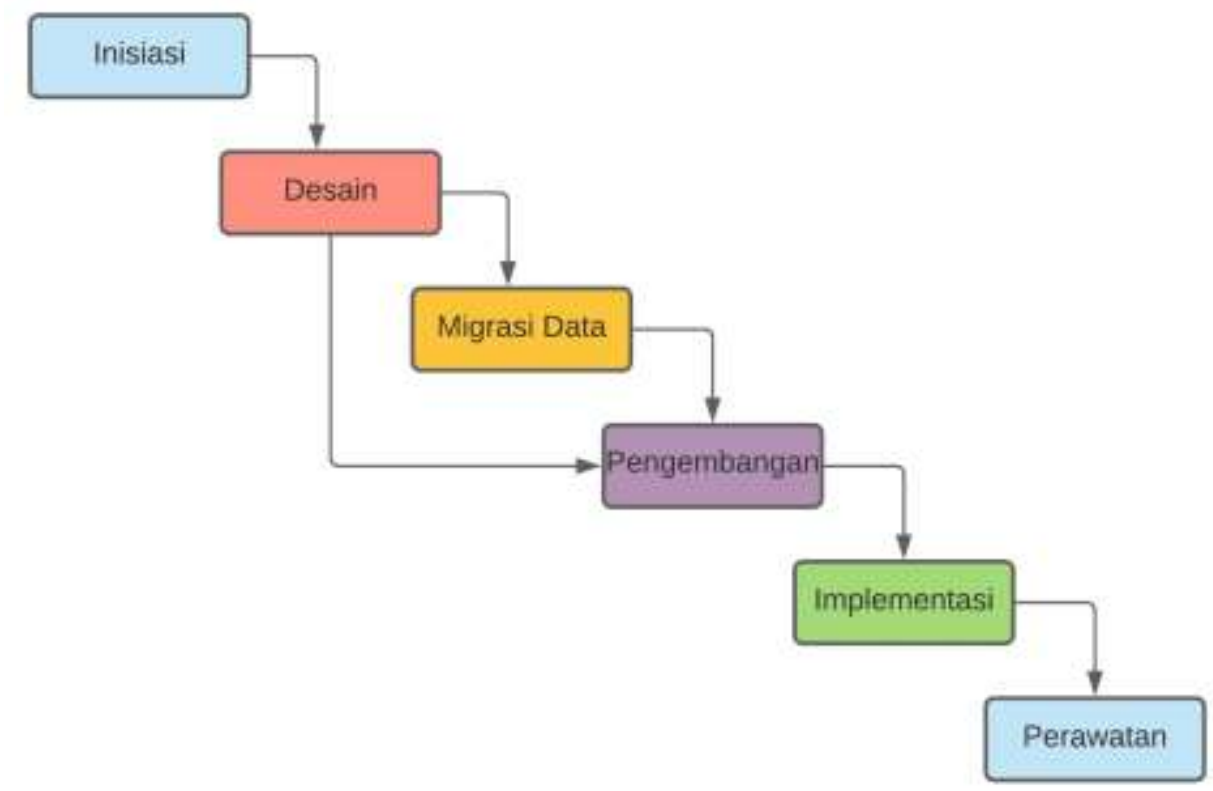

Gambar 1. Tahap Pelaksanaan

d) Pengembangan

Setelah desain dan rencana dari website sudah disetujui pada tim pelaksana akan langsung mengkustomisasi Wordpress beserta dengan plugin yang diperlukan, memastikan semua fitur dan fungsional dari website sudah disesuaikan dengan kebutuhan atau persyaratan pengguna (Klespitz, Bíró, \& Kovács, 2015).

e) Implementasi

Setelah website berhasil dikembangkan, maka langkah selanjutnya adalah melakukan uji coba secara internal, evaluasi ini dilakukan untuk memastikan semua fungsi sudah 
berjalan, data dan Informasi yang dibutuhkan oleh mitra sudah tersimpan dan tercatat kedalam sistem. Evaluasi layout dari User Interface (UI/UX) website berdasarkan desain sebelumnya juga sangat penting untuk memastikan persyaratan fungsional dan aspek non-fungsional sudah terpenuhi (Alomari, Ramasamy, Kiper, \& Potvin, 2020). Setelah evaluasi dilakukan, maka langkah selanjutnya adalah melakukan implementasi dan hosting website pada penyedia layanan hosting dan domain website. Pembimbingan dan pelatihan juga dilakukan, untuk meningkatkan pemahaman dari pengguna terkait dengan lingkungan website yang nantinya harus dikelola oleh bagian TIK Hotel Alvina

f) Perawatan

Setelah implementasi, sosialisasi dan pembimbingan dilakukan, maka fase selanjutnya yang menjamin keberlansungan implementasi dari website adalah perawatan. Perawatan meliputi aspek teknis dan non teknis yang ada pada website. Tim pelaksana akan menjamin proses perawatan ini selama 1 tahun, sampai mitra sudah mampu mengelola website-nya dengan mandiri.

\section{HASIL DAN PEMBAHASAN}

Untuk menggali kebutuhan atau persyaratan fungsional dan non fungsional dari website yang akan dikembangkan menggunakan instrumen wawancara dan daftar ceklis. Sesi wawancara dan analisis kebutuhan dilakukan 4 kali dengan melibatkan 2 orang pihak manajemen dan 2 orang pengelola TIK Hotel Alvina yaitu mulai dari 5 - 15 Januari 2021. Berikut beberapa pertanyaan dasar yang diajukan kepada mitra:

1. Sudah berapa lama anda bekerja disini?

2. Sejak kapan anda menggunakan internet?

3. Sejauh mana pemahaman anda tentang website?

4. Apakah promosi yang dilakukan selama ini sudah efektif?

5. Media apa yang anda gunakan untuk promosi hotel?

6. Sepenting apa website untuk promosi hotel anda?

7. Fitur-fitur apa yang anda inginkan dari website anda?
a. Product/Services
b. Contact
c. About
d. Testimonials
e. FAQ
f. $B \log$
g. Link
h. News
i. Booking
j. Pricing
k. Room view
l. Gallery
m. Tems \& Conditions
n. Social media link

8. Apakah fitur booking sangat penting?

9. Apakah dengan fitur-fitur yang sudah dipilih dapat meningkatkan promosi hotel?

a) Hasil wawancara

Berdasarkan wawancara dan daftar ceklis yang sudah dikumpulkan, didapatkan bahwa pihak manajemen dan pengelola TIK hotel menginginkan beberapa fungsional utama yang diperlukan dari website, diantaranya, yaitu adanya fitur view rooms yang berisi Informasi kamar, about us yang berisi Informasi hotel, fitur booking yang nantinya digunakan untuk reservasi bagi tamu hotel, fitur blog dan gallery yang nantinya dapat digunakan sebagai media promosi, dan 
halaman contact yang memberikan Informasi tentang keberadaan hotel, khususnya petunjuk dalam peta digital kota Pematangsiantar. Sementara terkait dengan kemampuan dan pengalaman dari pengelola TI berdasarkan hasil wawancara ternyata mereka mempunyai kemampuan yang cukup untuk implementasi dari website nantinya. Setelah kebutuhan utama didapatkan, langkah selanjutnya adalah melakukan analisis kebutuhan dengan memodelkan pada Use Case Diagram. Use Case Diagram digunakan karena cukup mudah dilihat dan dipahami oleh pengguna, sehingga kebutuhan yang sudah dimodelkan benar-benar akan mudah diidentifikasi oleh pengguna yang bersangkutan. Berikut akan dijelaskan hasil rinci dari analisis kebutuhan yang didapatkan, dan desain serta implementasi dari website yang berhasil dikembangkan.

b) Analisis Kebutuhan Website

Analisis kebutuhan dimodelkan dengan melihat pada 2 persyaratan yaitu persyaratan fungsional dan non fungsional. Berikut ini pada Gambar 2, akan digambarkan kebutuhan fungsional website.

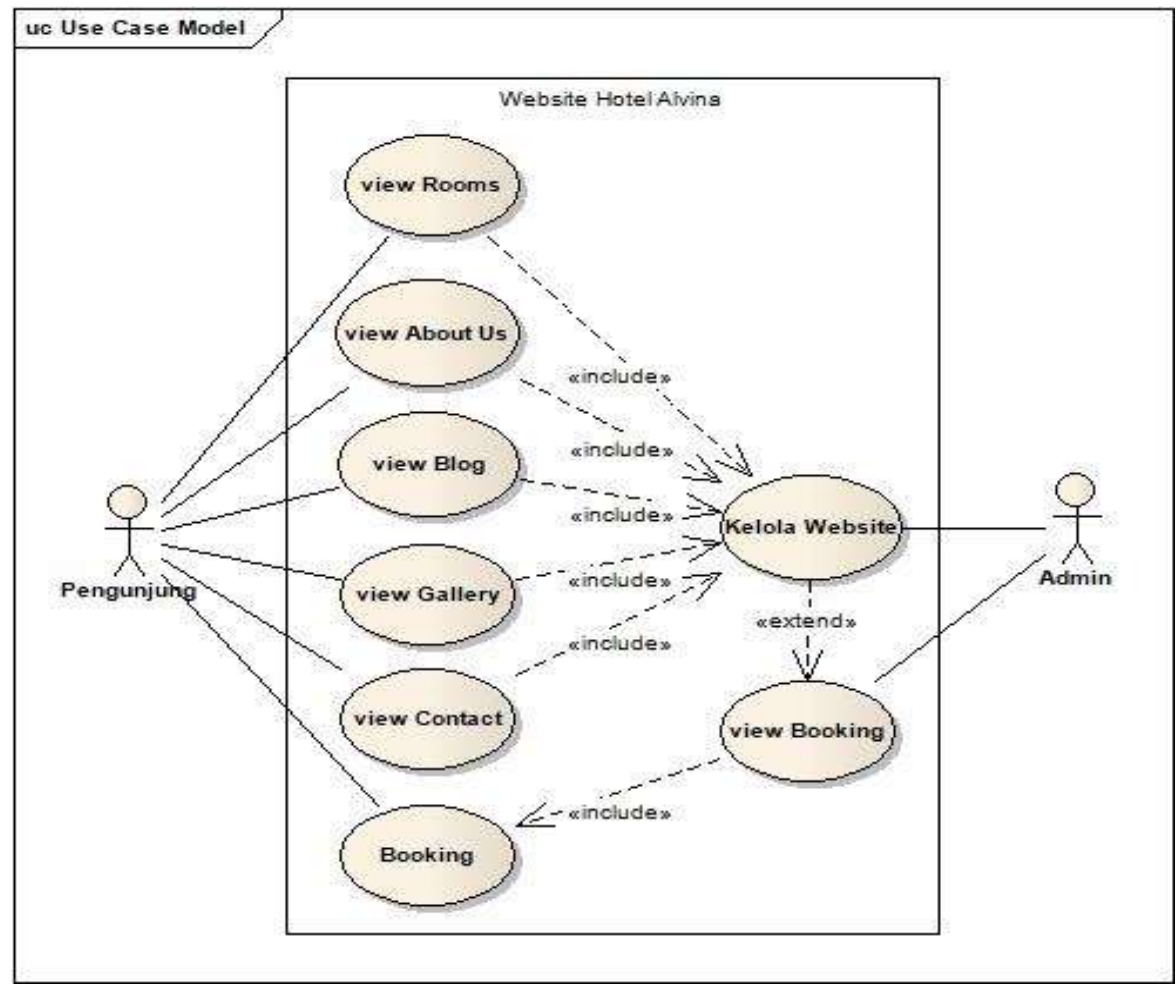

Gambar 2. Persyaratan Fungsional Website

Persyaratan fungsional apa saja yang pada website berdasarkan Gambar 2 diatas, bisa diuraikan sebagai berikut:

1. Secara umum user atau pengguna yang menggunakan website ini terdiri dari 2 jenis yaitu; Pengunjung dan Admin. Admin bertanggung jawab dalam pengelolaan semua fungsionalitas dari website, mulai dari mengelola rooms, gallery, about us, contact, dan booking.

2. Fungsional website yang bisa dilakukan oleh Pengunjung adalah melihat informasi kamar dan melakukan booking, melihat halaman about us, blog, gallery, dan contact. Pada saat proses booking dilakukan maka data akan disimpan dalam database dan akan terhubung ke halaman Admin dari website.

c) Desain dan Implementasi Website

Secara umum desain dan implementasi dari website Hotel Alvina sudah bisa di akses pada link berikut https://alvina.heboba.com/. Berdasarkan analisis fungsionalitas yang sudah 
dijelaskan sebelumnya, maka bisa diuraikan gambaran desain dan implementasi dari website adalah sebagai berikut:

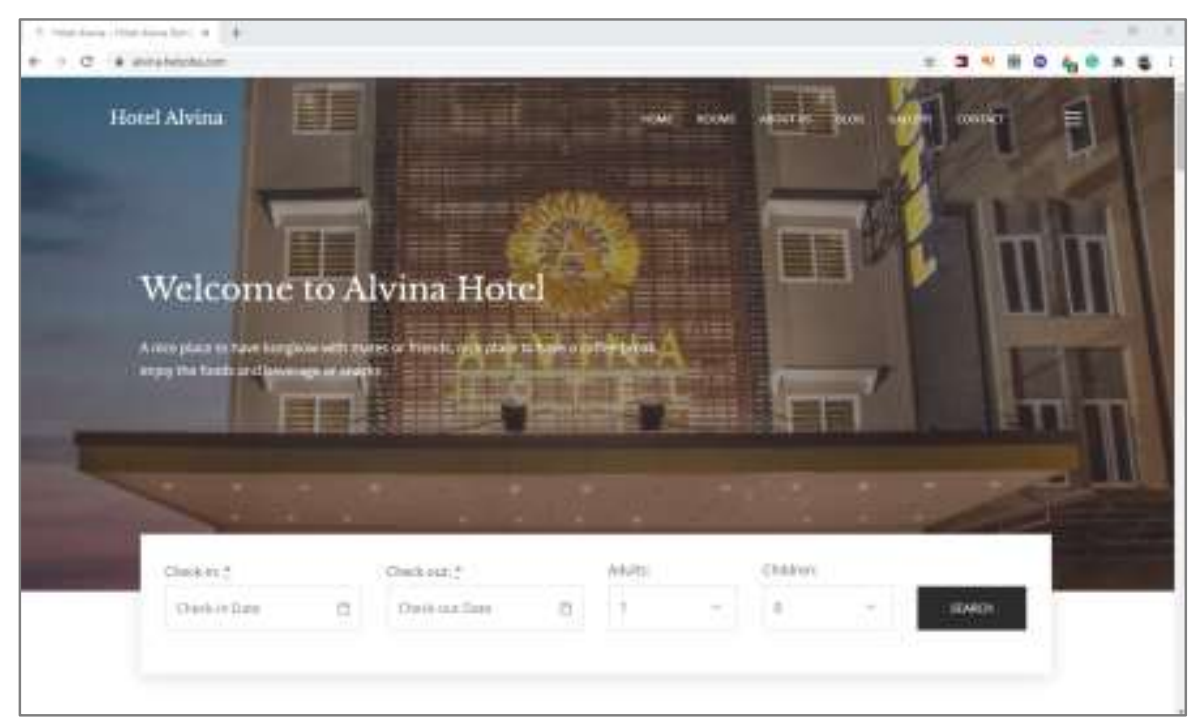

Gambar 3. Tampilan Halaman Depan Website

Tampilan halaman depan dari website pada Gambar 3 diatas, dapat dilihat bahwa ada 2 navigasi yaitu navigasi dari menu utama dan navigasi untuk melakukan reservasi atau booking. Fungsi booking dapat digunakan oleh pengunjung untuk mencari ketersediaan kamar dengan cara memasukkan tanggal Check-in, Check-out, jumlah orang dan menekan tombol Search. Maka nanti akan muncul informasi ketersediaan kamar yang dapat dilihat pada Gambar 4 berikut ini.

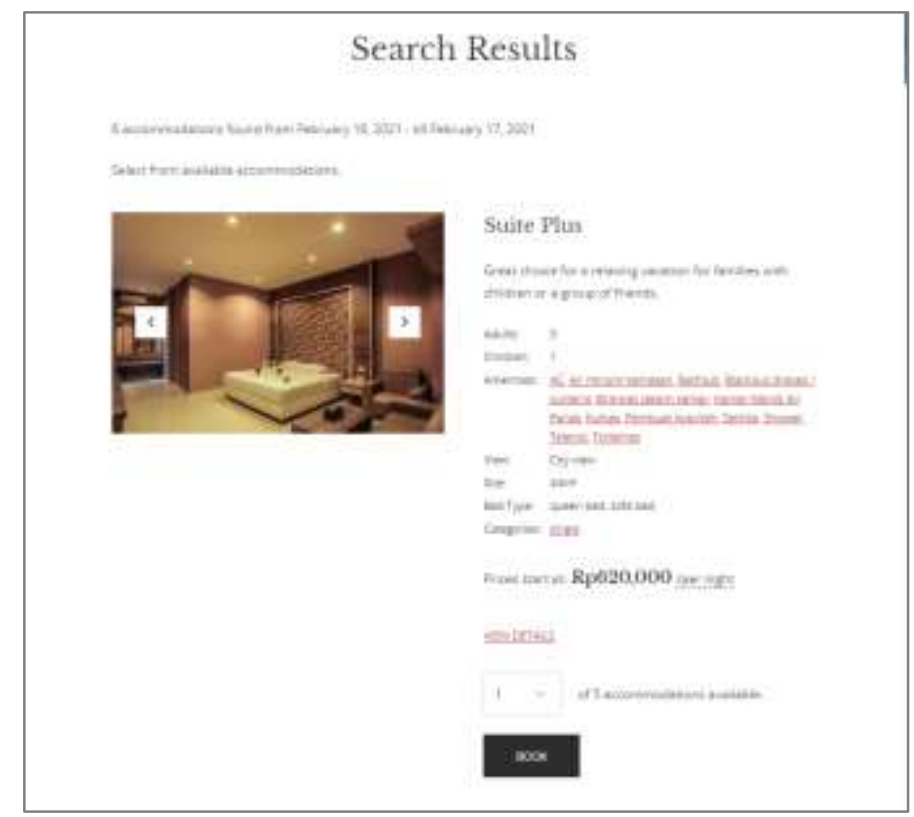

Gambar 4. Tampilan Halaman Booking

Setelah pengunjung memilih dan menentukan jenis kamar yang diinginkan, maka pengunjung dapat menekan tombol Book, maka website akan mengarahkan pengunjung untuk melakukan konfirmasi dengan cara mengklik tombol Confirm Reservation, dan pengunjung diminta untuk mengisi detail informasi booking, seperti nama, email, nomor telepon, asal negara, dan catatan penting yang akan diberikan kepada pengelola hotel, hal ini dapat dilihat pada Gambar 5 berikut. Setelah semua data diisi dengan lengkap, maka pengunjung dapat mengklik tombol Book Now. 


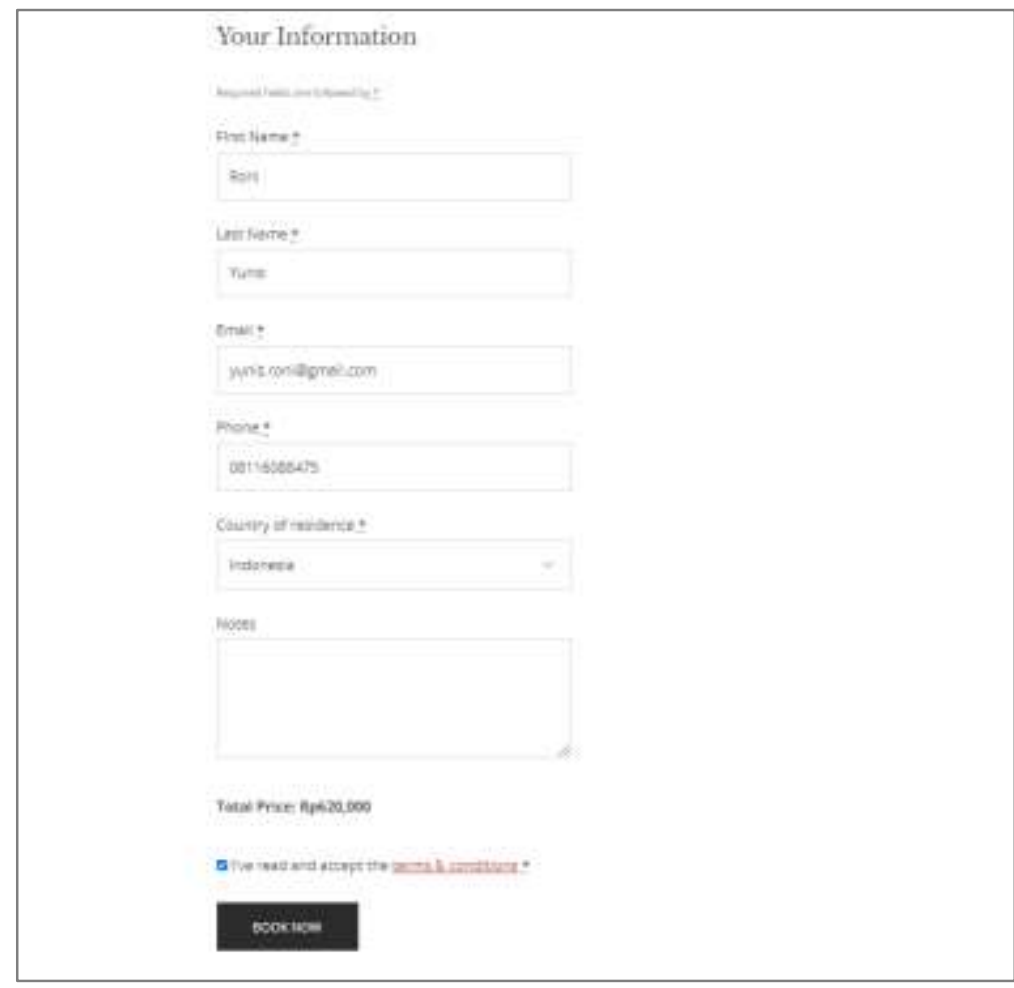

Gambar 5. Halaman Konfirmasi Booking

Setelah pengunjung mengklik tombol Book Now, maka aplikasi akan memunculkan pesan seperti Gambar 6 berikut, yang berisikan pesan bahwa reservasi sudah di kirim, dan informasi booking akan dikirimkan ke email pengunjung.

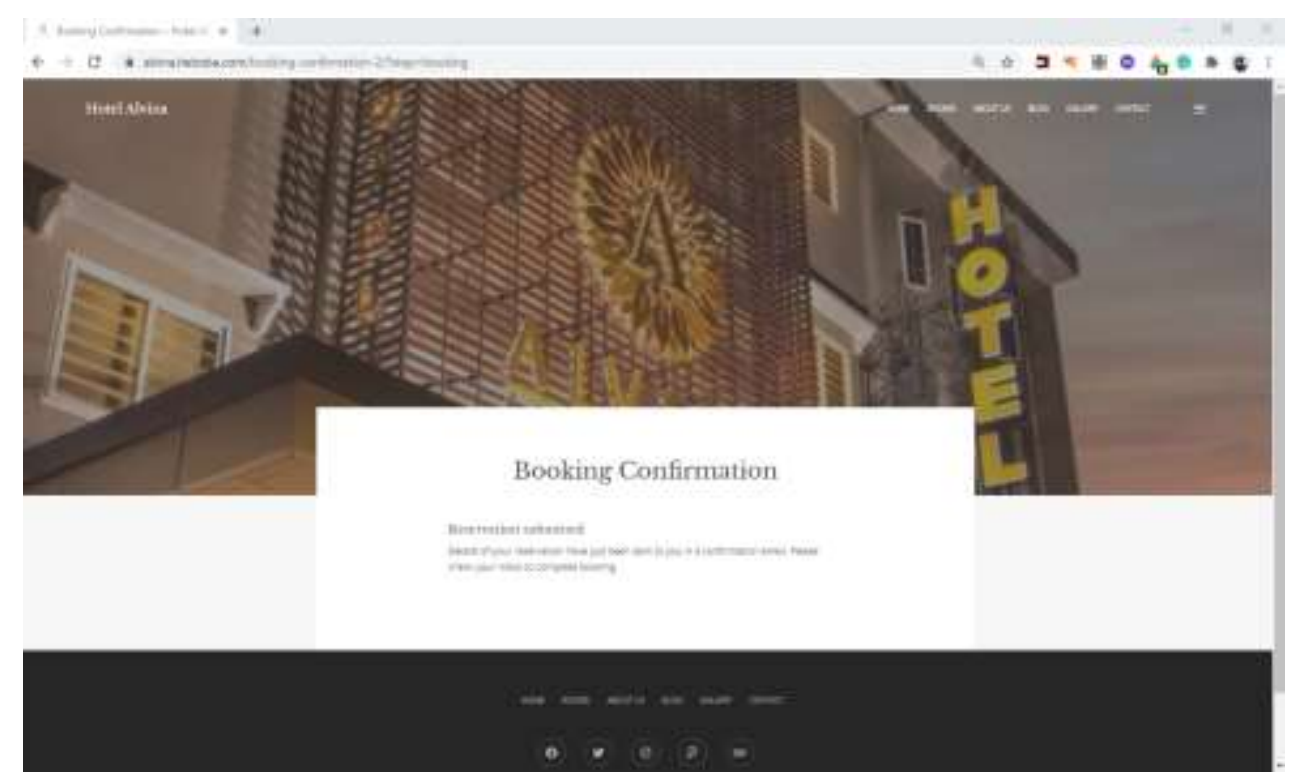

Gambar 6. Informasi Konfirmasi Booking

Pada Halaman About Us seperti pada Gambar 7 dapat digunakan oleh pihak Hotel untuk menyebarkan informasi kepada pengunjung terkait dengan informasi yang ada di Hotel. Setiap ada informasi berita terbaru bisa dimasukkan kedalam halaman About Us ini oleh Admin sehingga bisa dilihat oleh pengunjung dan diharapkan selalu di update setiap waktu. 


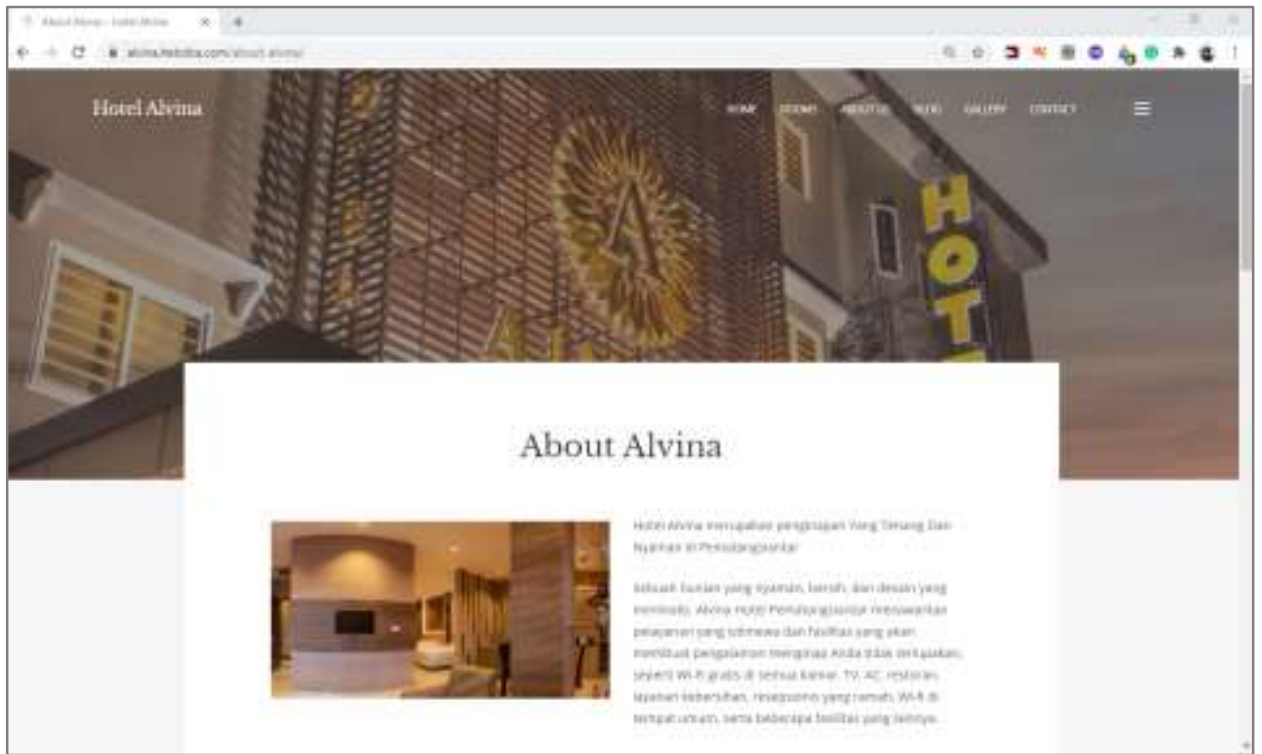

Gambar 7. Halaman About Us

Selain halaman About Us, website juga juga memiliki halaman Blog seperti Gambar 8 yang nantinya dapat digunakan untuk mengisi tulisan-tulisan tentang wisata dan objek wisata atau pengalaman wisata yang nantinya bisa dibaca oleh pengunjung. Sehingga hal ini bisa jadi daya Tarik pengunjung untuk berwisata di Pematangsiantar dan memilih akomodasinya di Hotel Alvina.

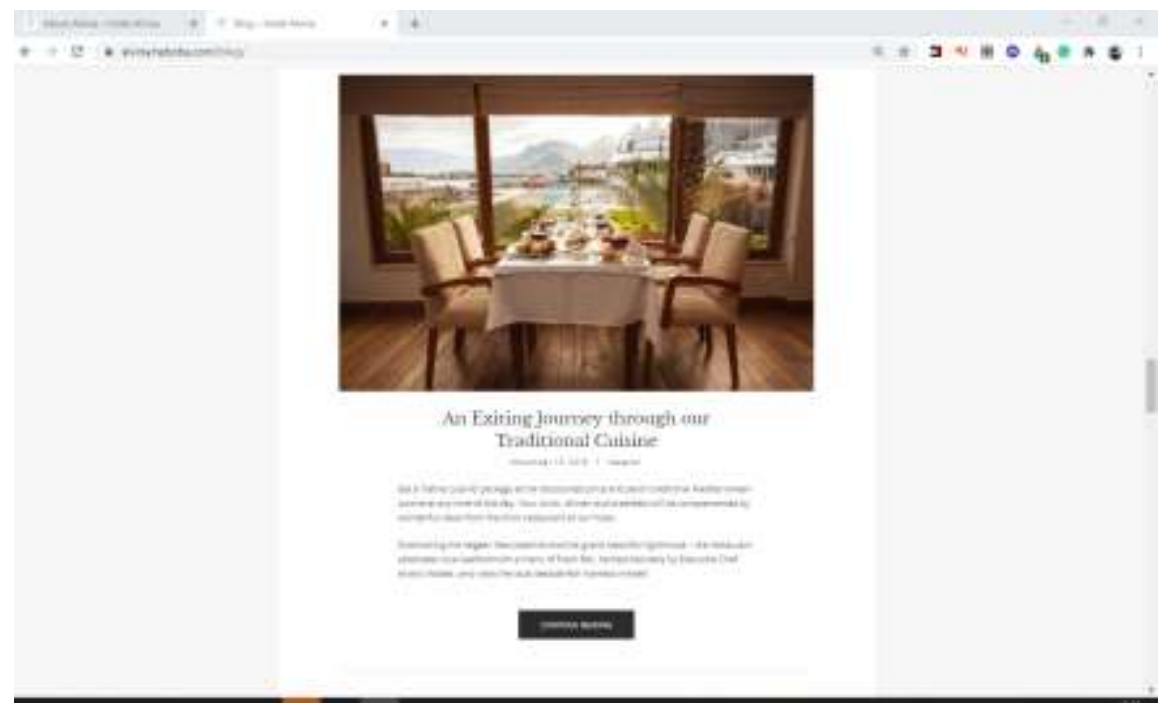

Gambar 8. Halaman Blog

Selain halaman Blog, dalam website ini juga ada halaman Contact Us seperti Gambar 9 yang berisi informasi alamat dan keberadaan dari Hotel yang terhubung ke google map, sehingga nantinya dapat dengan mudah dikunjungi oleh pengunjung atau tamu hotel. 


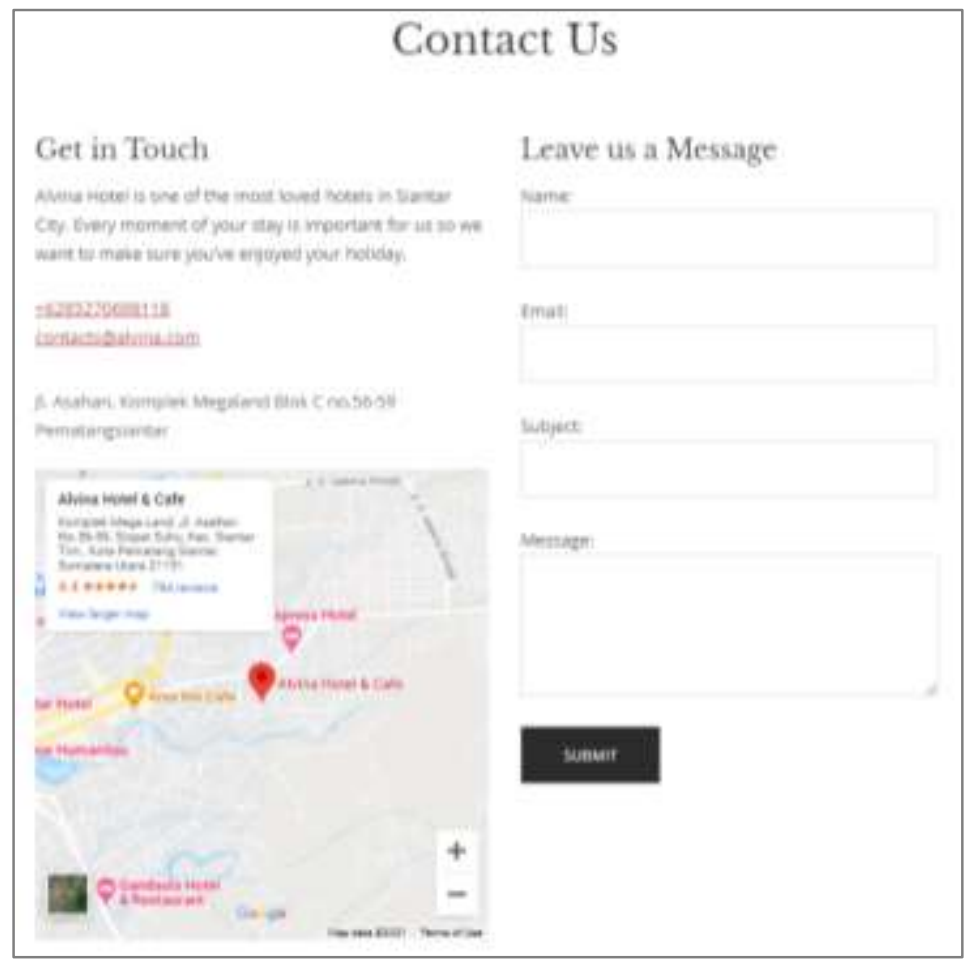

Gambar 9. Halaman Contact US

Halaman back-end dari website dapat di akses Admin pada link berikut https://alvina.heboba.com/wp-admin/. Admin yang akan mengelola website harus login terlebih dahulu dengan memasukkan username dan password yang sudah diperoleh sebelumnya.

Adapun beberapa bentuk desain dan implementasi dari halaman back-end tersebut bisa dilihat pada Gambar 10 berikut ini.

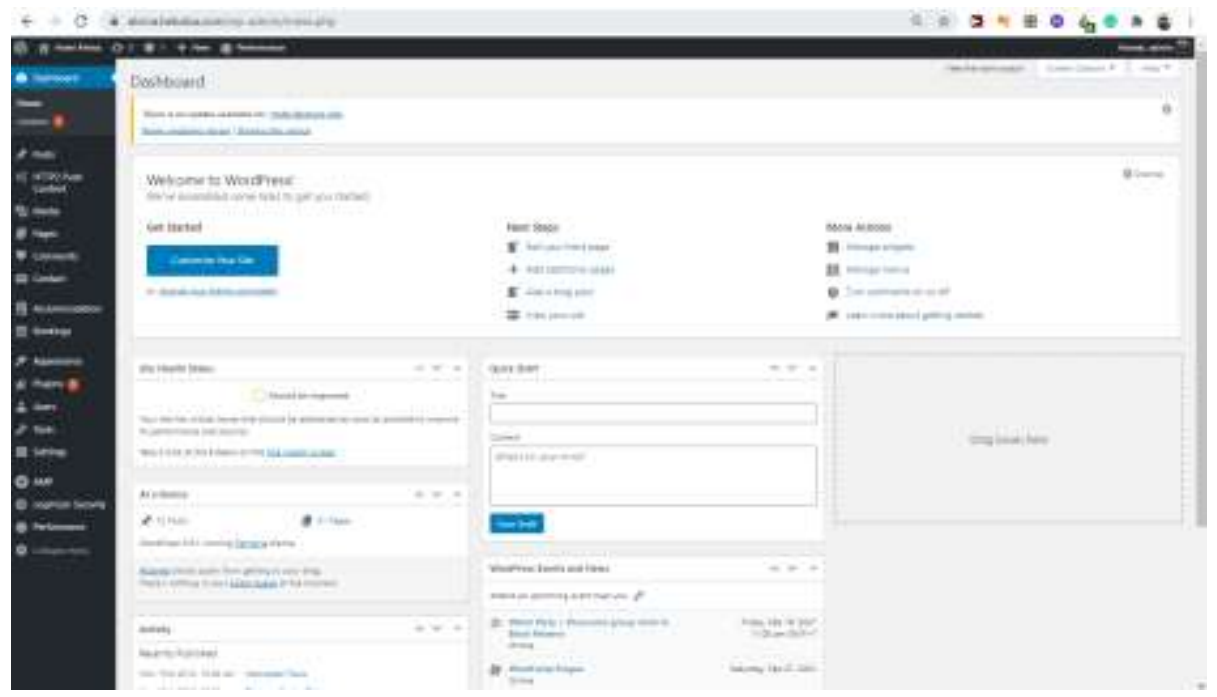

Gambar 10. Halaman Pengaturan Homepage Website

Halaman ini adalah halaman standar pengaturan homepage yang bisa digunakan oleh Admin untuk mengelola semua fungsionalitas yang ada pada halaman front-end website. Halaman pada Gambar 11 ini digunakan oleh Admin untuk mengelola halaman front-end website sehingga bisa dilihat dan diakses oleh penggunjung. 


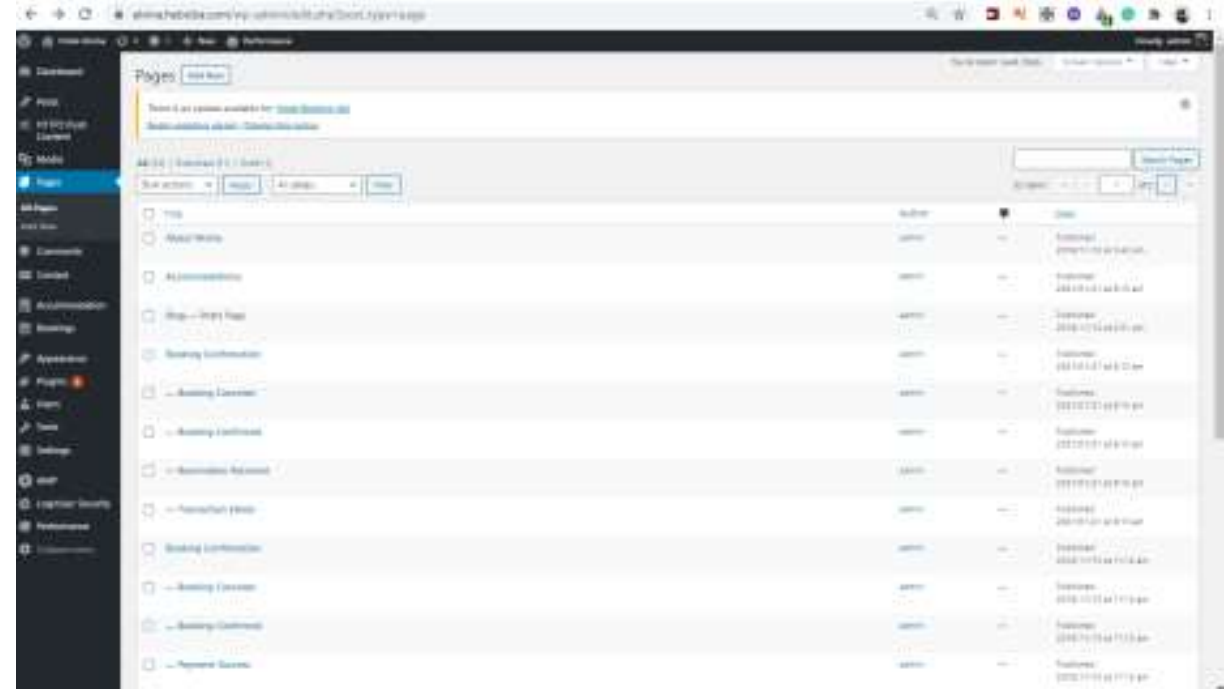

Gambar 11. Halaman pada Back-End Website

d) Sosialiasi dan Pembimbingan

Kegiatan sosialiasi dilakukan secara langsung pada mitra, dengan cara memberikan pengenalan dan pembimbingan pada penggunaan website beserta dengan fitur-fitur yang ada didalamnya. Berdasarkan hasil evaluasi secara kualitatif terhadap penggunaan website oleh mitra, ternyata mitra sangat puas dan mudah menggunakan fitur-fitur yang ada didalamnya, terutama pada bagian backend sistem. Untuk menjamin keberlansungan implementasi dari website sampai saat ini perawatan dari website langsung diambil alih oleh tim pelaksana PkM sampai 1 tahun kedepan, sehingga kalau ada kendala selama penggunaan website tersebut maka, mitra bisa menghubungi secara langsung tim pelaksana untuk melakukan perawatan.

\section{KESIMPULAN}

Berdasarkan hasil yang dicapai dari pelaksanaan PkM yang sudah dilakukan, maka dapat diambil beberapa kesimpulan sebagai berikut:

a) PkM yang sudah berhasil dilaksanakan menghasilkan sebuah Website yang diharapkan dapat menjadi salah satu media penguatan promosi dan bisnis dari Hotel Alvina menjadi lebih baik lagi;

b) Website yang dikembangkan dapat dengan mudah digunakan untuk reservasi bagi tamutamu Hotel Alvina;

c) Melalui sosialisasi dan pembimbingan yang akan dilakukan dalam program PkM diharapkan dapat memberikan dampak positif bagi pengelola TIK yang bertanggung jawab dalam manajemen website Hotel Alvina;

\section{UCAPAN TERIMA KASIH}

Terima kasih disampaikan kepada STMIK Mikroskil atas Hibah Kompetisi Internal Kreativitas \& Inovasi Dosen untuk bidang Pengabdian kepada Masyarakat yang diterima dan sesuai dengan surat perjanjian pelaksanaan Nomor 1870/ST.45/01/PM/2020, tanggal 23 Desember 2020.

\section{DAFTAR PUSTAKA}

Alomari, H. W., Ramasamy, V., Kiper, J. D., \& Potvin, G. (2020). A User Interface (UI) and User eXperience (UX) evaluation framework for cyberlearning environments in computer science and software engineering education. Heliyon, 6(5), e03917. 
https://doi.org/10.1016/j.heliyon.2020.e03917

Andriyan, W., Septiawan, S., \& Aulya, A. (2020). Perancangan Website Sebagai Media Informasi dan Peningkatan Citra pada SMK Dewi Sartika Tangerang. 6(2), 79-88.

Hills, M. (2016). Navigating the WordPress Plugin Landscape. International Conference on Program Comprehension, $1-10$. https://doi.org/https://doi.org/10.1109/ICPC.2016.7503709

Joo, H. (2017). A study on understanding of UI and UX, and understanding of design according to user interface change. International Journal of Applied Engineering Research, 12(20), 99319935.

Khadafi, S., Salim, A., \& Prabowo, R. (2018). Rancang Bangun Website UKM Reviora Tanggulangin Sidoarjo Menggunakan Metode Waterfall Sebagai Media Pemasaran Online. 705-710.

Klespitz, J., Bíró, M., \& Kovács, L. (2015). Aspects of improvement of software development lifecycle management. 323-327.

Patel, K, S., Rathod, R, V., \& Parikh, S. (2011). Joomla, Drupal and Wordpress - A Statistical Comparison of Open Source CMS. 182-187.

Pemkot. (2021). Sejarah Kota Pematangsiantar. Retrieved February 26, 2021, from Pemkot Pematangsiantar website: http://pematangsiantarkota.go.id/statis-124/sejarah-kotapematangsiantar.html

Sugiantoro, B., Anshari, M., \& Sudrajat, D. (2020). Developing Framework for Web Based eCommerce : Deve. 1-8. https://doi.org/10.1088/1742-6596/1566/1/012020

Wisata, P. (2021). 20 Tempat Wisata di Siantar yang Paling Hits dan Kekinian yang Wajib Dikunjungi. Retrieved February 26, 2021, from Portal Wisata website: https://portalwisata.co.id/tempat-wisata-di-siantar/ 